physical and mental health of migrants. Clearly, further research is needed to determine the factors responsible for different ethnic groups developing atheroma. We must remember, however, that the presentation of coronary heart disease as myocardial infarction and sudden death depends on the behaviour of the atherosclerotic lesion, including factors like rupture of the plaque. These factors may well be different in different ethnic populations, but this question has never been addressed.

Consultant Cardiologist

KIM M FOX

National Heart Hospital

London W1M 8BA

Consultant Cardiologist,

Papworth Hospital,

Papworth Everard,

Cambridgeshire

1 Balarajan R, Bulusu L, Adelstein AM, Shukla V. Patterns of mortality among migrants to England and Wales from the Indian subcontinent. Br.Med 7 1984;289:1185-7.
2 Marmot MG, Adelstein AM, Bulusu L. Lessons from the study of immigrant mortality. Lancet $1984 ;$;: $1455-7$.

3 Cruickshank JK, Beevers DG, Osbourne VL, Haynes RA, Corlett JCR, Selby S. Heart attack, stroke, diabetes, and hypertension in West Indians, Asians, and whites in Birmingham, England. Br Med f 1980;281:1108.

4 Lawrence RE, Littler WA. Acute myocardial infarction in Asians and whites in Birmingham. BrMed J 1985;290:1472.

5 Beevers DG, Cruickshank JK. Age, sex, ethnic origin and hospital admission for heart attack and stroke. Postgrad Med f 1981;57:763-5.

6 Beckles GLA, Miller GH, Kirkwood BR, Alexis SD, Carson DC, Byam NTA. High total and cardiovascular disease mortality in adults of Indian descent in Trinidad, unexplained by major coronary risk factors. Lancet 1986;i:1298-1301.

Shaper AG, Jones KW. Serum cholesterol, diet and coronary heart disease in Africans and Asians in Uganda. Lancet 1959;ii:534-7.

8 Danaraj TJ, Acker MS, Danaraj W, Wong Hee Ong, Tan Bock Yam. Ethnic group differences in coronary heart disease in Singapore: an analysis of necropsy records. Am Heart f 1959;58:516-26. Lower PJ, Glover DR, Mace PJE, Littler WA. Coronary artery disease in Asians in Birmingham. Br Heart f 1982;S2:610.3

10 Coronary Prevention Group Coronary heart disease and Asians in Britain. London: CPG and Confederation of Indian Organisations (United Kingdom), 1986. (Available from the Confederation of Indian Organisations, 5-5A Westminster Bridge Road, London SE1 7XW; price

1 Marmot MG, Adelstein AM, Bulusu L. Cardiovascular mortality among immigrants to England and Wales. Postgrad Med F 1981;57:760-2.

12 McKeigue PM, Marmot MG, Adelstein AM, et al. Diet and risk factors for coronary heart disease in Asians in northwest London. Lancet 1985 ;ii: 1086-90.

13 Padhani A, Dandona P. Diabetes and coronary heart disease in north London Asians. Lancel 1986;i:213-4.

14 Jacobson MS. Cholesterol oxides in Indian ghee: possible cause of unexplained high risk of atherosclerosis in Indian immigrant populations. Lancet 1987;ii:656-8.

\title{
A European CSM?
}

\section{The future of British drug regulation lies in Europe}

The European Community aims at creating a fully integrated internal market by 1992, and this will naturally apply to pharmaceutical products. The community is likely to extend and drastically revise the legislation for licensing medicines within Europe, and ultimately decisions on whether a medicine is to be marketed in Britain may be taken in Europe rather than in Britain.

When Britain joined the European Community in 1973 it already had a machinery for regulating medicines, and the community had a directive with three aims: to set rules on producing and distributing proprietary medicines that would safeguard public health; to attain the first aim without hindering the development of the pharmaceutical industry; and to eliminate disparities affecting the internal market. European directives do not have to be translated exactly into national laws, but when national legislation and a European Community directive are at variance the directive takes precedence.

European Community directives issued in 1976 set up a procedure whereby after a product had been approved for marketing in one member state other countries could recognise the first country's assessment and issue their own national marketing authorisation. Mutual recognition should have led to a collection of national marketing authorisations for each medicine. In the same year the community also set up the Committee on Proprietary Medicinal Products to consider cases in which national regulatory authorities had taken divergent opinions on whether to approve a medicine for licensing.

The Committee on Proprietary Medicinal Products soon recognised that the system had been set up before the standards set by national authorities had been adequately harmonised. Therefore it set up working parties to produce detailed guidelines on three issues: evaluating safety (covering acute toxicity, repeated dose toxicity, carcinogenicity, mutagenicity, and pharmacokinetics); testing efficacy; and harmonising the dossier that pharmaceutical companies have to present for marketing approval in each of the member states. This multistate procedure has now been modified to allow companies to appeal to the Committee on Proprietary
Medicinal Products if it reaches an adverse opinion on their products.

Mutual recognition has not worked well. In 12 years no licence granted in one country has been unequivocally recognised in another. The European Commission has recently produced a report on the current procedures and has to produce recommendations for future improvements by the end of 1988. Fundamental changes are clearly inevitable. Furthermore, new proposals will need to be radical because so many national regulatory authorities are failing to cope with their existing workload. In Britain and West Germany approvals for new products are taking two to six times longer than the limits laid down by the community-that is, 120 days with an additional 90 days in exceptional circumstances (such as when referral to an advisory committee is necessary).

The commission might propose a central authority for registering all innovative products and products of biotechnology. Such a procedure of making decisions centrally was foreshadowed in 1987, when a directive known as the High Technology Directive set up a mechanism whereby the Committee on Proprietary Medicinal Products would consider applications for new biotechnology products and give an opinion before they were considered in individual countries. The committee's opinion is not binding on member states, but changes could be introduced to make these "opinions" into "binding decisions." This procedure should allow greater harmonisation, but any centralised European regulatory body set up should probably be independent of the existing machinery of the Committee on Proprietary Medicinal Products. The question of whom such a body would be accountable to has yet to be resolved. Adequate input from expert advisory bodies would be essential if such a system were to have the confidence of the public and professions. It seems, however, that the future of regulating medicines lies in the European Community rather than in the individual member states.

Director,

JOHN P GRIFFIN

Association of the British Pharmaceutical Industry,

London SW 1A 2DY 